\title{
Prolactin-releasing peptide receptor in GtoPdb v.2021.3
}

\author{
Vanni Caruso ${ }^{1}$, Rebecca Hills ${ }^{2}$, Malin Lagerstrom ${ }^{3}$, Tatsushi Onaka ${ }^{4}$ and Helgi Schiöth ${ }^{3}$
}

1. University of Tasmania, Australia

2. University of Edinburgh, UK

3. Uppsala University, Sweden

4. Jichi Medical University, Japan

\begin{abstract}
The precursor ( $P R L H$, P81277) for PrRP generates 31 and 20-amino-acid versions. QRFP43 (43RFa) (named after a pyroglutamylated arginine-phenylalanine-amide peptide) is a 43 amino acid peptide derived from QRFP (P83859) and is also known as P518 or 26RFa. RFRP is an RF amide-related peptide [31] derived from a FMRFamide-related peptide precursor (NPVF, Q9HCQ7), which is cleaved to generate neuropeptide SF, neuropeptide RFRP-1, neuropeptide RFRP-2 and neuropeptide RFRP-3 (neuropeptide NPVF).
\end{abstract}

\section{Contents}

This is a citation summary for Prolactin-releasing peptide receptor in the Guide to Pharmacology database (GtoPdb). It exists purely as an adjunct to the database to facilitate the recognition of citations to and from the database by citation analyzers. Readers will almost certainly want to visit the relevant sections of the database which are given here under database links.

GtoPdb is an expert-driven guide to pharmacological targets and the substances that act on them. GtoPdb is a reference work which is most usefully represented as an on-line database. As in any publication this work should be appropriately cited, and the papers it cites should also be recognized. This document provides a citation for the relevant parts of the database, and also provides a reference list for the research cited by those parts. For further details see [9].

Please note that the database version for the citations given in GtoPdb are to the most recent preceding version in which the family or its subfamilies and targets were substantially changed. The links below are to the current version. If you need to consult the cited version, rather than the most recent version, please contact the GtoPdb curators.

\section{Database links}

Prolactin-releasing peptide receptor

https://www.guidetopharmacology.org/GRAC/FamilyDisplayForward?familyId=57

Introduction to Prolactin-releasing peptide receptor

https://www.guidetopharmacology.org/GRAC/FamilyIntroductionForward?familyId=57

Receptors

PrRP receptor

https://www.guidetopharmacology.org/GRAC/ObjectDisplayForward?objectId=337

\section{References}

1. Abe T, Koga N, Tomita M, Tonoike T, Kushima M, Takahashi K, Sano Y and Taniyama M. (2003) Cellular localization of prolactin-releasing peptide receptors in the human pituitary. Acta Neuropathol 106: 495-500 [PMID:12915950]

2. Adán N, Guzmán-Morales J, Ledesma-Colunga MG, Perales-Canales SI, Quintanar-Stéphano A, López-Barrera F, Méndez I, Moreno-Carranza B, Triebel J and Binart N et al.. (2013) Prolactin promotes cartilage survival and attenuates inflammation in inflammatory arthritis. J Clin Invest 123: 3902-13 [PMID:23908112]

3. Ascencio-Cedillo R, López-Pulido EI, Muñoz-Valle JF, Villegas-Sepúlveda N, Del Toro-Arreola S, 
Estrada-Chávez C, Daneri-Navarro A, Franco-Topete R, Pérez-Montiel D and García-Carrancá A et al.. (2015) Prolactin and prolactin receptor expression in cervical intraepithelial neoplasia and cancer. Pathol Oncol Res 21: 241-6 [PMID:24990775]

4. Auffret J, Freemark M, Carré N, Mathieu Y, Tourrel-Cuzin C, Lombès M, Movassat J and Binart N. (2013) Defective prolactin signaling impairs pancreatic $\beta$-cell development during the perinatal period. Am J Physiol Endocrinol Metab 305: E1309-18 [PMID:24064341]

5. Bernard V, Young J, Chanson P and Binart N. (2015) New insights in prolactin: pathological implications. Nat Rev Endocrinol 11: 265-75 [PMID:25781857]

6. Bhattacharyya S, Luan J, Challis B, Schmitz C, Clarkson P, Franks PW, Middelberg R, Keogh J, Farooqi IS and Montague C et al.. (2003) Association of polymorphisms in GPR10, the gene encoding the prolactin-releasing peptide receptor with blood pressure, but not obesity, in a U.K. Caucasian population. Diabetes 52: 1296-9 [PMID:12716769]

7. Bogorad RL, Courtillot C, Mestayer C, Bernichtein S, Harutyunyan L, Jomain JB, Bachelot A, Kuttenn F, Kelly PA and Goffin V et al.. (2008) Identification of a gain-of-function mutation of the prolactin receptor in women with benign breast tumors. Proc Natl Acad Sci USA 105: 14533-8 [PMID:18779591]

8. Bole-Feysot C, Goffin V, Edery M, Binart N and Kelly PA. (1998) Prolactin (PRL) and its receptor: actions, signal transduction pathways and phenotypes observed in PRL receptor knockout mice. Endocr Rev 19: 225-68 [PMID:9626554]

9. Buneman P, Christie G, Davies JA, Dimitrellou R, Harding SD, Pawson AJ, Sharman JL and Wu Y. (2020) Why data citation isn't working, and what to do about it Database 2020

[PMID:32367113]

10. Champagne D, Beaulieu J and Drolet G. (1998) CRFergic innervation of the paraventricular nucleus of the rat hypothalamus: a tract-tracing study. J Neuroendocrinol 10: 119-31 [PMID:9535058]

11. Chen WY. (2015) The many faces of prolactin in breast cancer. Adv Exp Med Biol 846: 61-81 [PMID:25472534]

12. Costanza M, Binart N, Steinman L and Pedotti R. (2015) Prolactin: a versatile regulator of inflammation and autoimmune pathology. Autoimmun Rev 14: 223-30 [PMID:25462579]

13. Courtillot C, Chakhtoura Z, Bogorad R, Genestie C, Bernichtein S, Badachi Y, Janaud G, Akakpo JP, Bachelot A and Kuttenn F et al.. (2010) Characterization of two constitutively active prolactin receptor variants in a cohort of 95 women with multiple breast fibroadenomas. J Clin Endocrinol Metab 95: 271-9 [PMID:19897676]

14. Curlewis JD, Kusters DH, Barclay JL and Anderson ST. (2002) Prolactin-releasing peptide in the ewe: cDNA cloning, mRNA distribution and effects on prolactin secretion in vitro and in vivo. $J$ Endocrinol 174: 45-53 [PMID:12098662]

15. Damiano JS, Rendahl KG, Karim C, Embry MG, Ghoddusi M, Holash J, Fanidi A, Abrams TJ and Abraham JA. (2013) Neutralization of prolactin receptor function by monoclonal antibody LFA102, a novel potential therapeutic for the treatment of breast cancer. Mol Cancer Ther 12: 295-305 [PMID:23270929]

16. Damiano JS and Wasserman E. (2013) Molecular pathways: blockade of the PRLR signaling pathway as a novel antihormonal approach for the treatment of breast and prostate cancer. Clin Cancer Res 19: 1644-50 [PMID:23515410]

17. Davis XS and Grill HJ. (2018) The hindbrain is a site of energy balance action for prolactinreleasing peptide: feeding and thermic effects from GPR10 stimulation of the nucleus tractus solitarius/area postrema. Psychopharmacology (Berl.) 235: 2287-2301 [PMID:29796829]

18. Ellacott KL, Donald EL, Clarkson P, Morten J, Masters D, Brennand J and Luckman SM. (2005) Characterization of a naturally-occurring polymorphism in the UHR-1 gene encoding the putative rat prolactin-releasing peptide receptor. Peptides 26: 675-81 [PMID:15752583]

19. Ellacott KL, Lawrence CB, Rothwell NJ and Luckman SM. (2002) PRL-releasing peptide interacts with leptin to reduce food intake and body weight. Endocrinology 143: 368-74 [PMID:11796488]

20. Engström M, Brandt A, Wurster S, Savola JM and Panula P. (2003) Prolactin releasing peptide has high affinity and efficacy at neuropeptide FF2 receptors. J Pharmacol Exp Ther 305: 825-32 [PMID:12606605]

21. Fredriksson R, Lagerström MC, Lundin LG and Schiöth HB. (2003) The G-protein-coupled receptors in the human genome form five main families. Phylogenetic analysis, paralogon groups, and fingerprints. Mol Pharmacol 63: 1256-72 [PMID:12761335]

22. Fujii R, Fukusumi S, Hosoya M, Kawamata Y, Habata Y, Hinuma S, Sekiguchi M, Kitada C, Kurokawa T and Nishimura O et al.. (1999) Tissue distribution of prolactin-releasing peptide (PrRP) and its receptor. Regul Pept 83: 1-10 [PMID:10498338]

23. Grabauskas G, Zhou SY, Das S, Lu Y, Owyang C and Moises HC. (2004) Prolactin-releasing peptide affects gastric motor function in rat by modulating synaptic transmission in the dorsal vagal complex. J Physiol (Lond.) 561: 821-39 [PMID:15486017]

24. Grattan DR. (2015) 60 YEARS OF NEUROENDOCRINOLOGY: The hypothalamo-prolactin axis. $J$ 
Endocrinol 226: T101-22 [PMID:26101377]

25. Gu W, Geddes BJ, Zhang C, Foley KP and Stricker-Krongrad A. (2004) The prolactin-releasing peptide receptor (GPR10) regulates body weight homeostasis in mice. J Mol Neurosci 22: 93103 [PMID:14742914]

26. Hadley ME and Haskell-Luevano C. (1999) The proopiomelanocortin system. Ann N Y Acad Sci 885: 1-21 [PMID:10816638]

27. Hanna CW, Bretherick KL, Liu CC, Stephenson MD and Robinson WP. (2010) Genetic variation within the hypothalamus-pituitary-ovarian axis in women with recurrent miscarriage. Hum Reprod 25: 2664-71 [PMID:20716560]

28. Hartwell HJ, Petrosky KY, Fox JG, Horseman ND and Rogers AB. (2014) Prolactin prevents hepatocellular carcinoma by restricting innate immune activation of c-Myc in mice. Proc Natl Acad Sci USA 111: 11455-60 [PMID:25049387]

29. Hilfiker-Kleiner D, Kaminski K, Podewski E, Bonda T, Schaefer A, Sliwa K, Forster O, Quint A, Landmesser U and Doerries C et al.. (2007) A cathepsin D-cleaved $16 \mathrm{kDa}$ form of prolactin mediates postpartum cardiomyopathy. Cell 128: 589-600 [PMID:17289576]

30. Hinuma S, Habata Y, Fujii R, Kawamata Y, Hosoya M, Fukusumi S, Kitada C, Masuo Y, Asano T and Matsumoto $\mathrm{H}$ et al.. (1998) A prolactin-releasing peptide in the brain. Nature 393: 272-6 [PMID:9607765]

31. Hinuma S, Shintani Y, Fukusumi S, Iijima N, Matsumoto Y, Hosoya M, Fujii R, Watanabe T, Kikuchi K and Terao Y et al.. (2000) New neuropeptides containing carboxy-terminal RFamide and their receptor in mammals. Nat Cell Biol 2: 703-8 [PMID:11025660]

32. Holubová M, Hrubá L, Neprašová B, Majerčíková Z, Lacinová Z, Kuneš J, Maletínská L and Železná B. (2018) Prolactin-releasing peptide improved leptin hypothalamic signaling in obese mice. J Mol Endocrinol 60: 85-94 [PMID:29233862]

33. Horiuchi J, Saigusa T, Sugiyama N, Kanba S, Nishida Y, Sato Y, Hinuma S and Arita J. (2002) Effects of prolactin-releasing peptide microinjection into the ventrolateral medulla on arterial pressure and sympathetic activity in rats. Brain Res 958: 201-9 [PMID:12468046]

34. Huang C, Snider F and Cross JC. (2009) Prolactin receptor is required for normal glucose homeostasis and modulation of beta-cell mass during pregnancy. Endocrinology 150: 1618-26 [PMID:19036882]

35. Iijima N, Matsumoto Y, Yano T, Tanaka M, Yamamoto T, Kakihara K, Kataoka Y, Tamada Y, Matsumoto $\mathrm{H}$ and Suzuki N et al.. (2001) A novel function of prolactin-releasing peptide in the control of growth hormone via secretion of somatostatin from the hypothalamus. Endocrinology 142: 3239-43 [PMID:11416047]

36. Kalliomäki ML, Pertovaara A, Brandt A, Wei H, Pietilä P, Kalmari J, Xu M, Kalso E and Panula P. (2004) Prolactin-releasing peptide affects pain, allodynia and autonomic reflexes through medullary mechanisms. Neuropharmacology 46: 412-24 [PMID:14975697]

37. Lagerström MC, Fredriksson R, Bjarnadóttir TK, Fridmanis D, Holmquist T, Andersson J, Yan YL, Raudsepp T, Zoorob R and Kukkonen JP et al.. (2005) Origin of the prolactin-releasing hormone (PRLH) receptors: evidence of coevolution between PRLH and a redundant neuropeptide Y receptor during vertebrate evolution. Genomics 85: 688-703 [PMID:15885496]

38. Langmead CJ, Szekeres PG, Chambers JK, Ratcliffe SJ, Jones DN, Hirst WD, Price GW and Herdon HJ. (2000) Characterization of the binding of [(125)I]-human prolactin releasing peptide (PrRP) to GPR10, a novel G protein coupled receptor. Br J Pharmacol 131: 683-8 [PMID:11030716]

39. Laurent P, Becker JA, Valverde O, Ledent C, de Kerchove d'Exaerde A, Schiffmann SN, Maldonado R, Vassart G and Parmentier M. (2005) The prolactin-releasing peptide antagonizes the opioid system through its receptor GPR10. Nat Neurosci 8: 1735-41 [PMID:16299503]

40. Lawrence CB, Celsi F, Brennand J and Luckman SM. (2000) Alternative role for prolactinreleasing peptide in the regulation of food intake. Nat Neurosci 3: 645-6 [PMID:10862694]

41. Lawrence CB, Ellacott KL and Luckman SM. (2002) PRL-releasing peptide reduces food intake and may mediate satiety signaling. Endocrinology 143: 360-7 [PMID:11796487]

42. Lawrence CB, Liu YL, Stock MJ and Luckman SM. (2004) Anorectic actions of prolactinreleasing peptide are mediated by corticotropin-releasing hormone receptors. Am J Physiol Regul Integr Comp Physiol 286: R101-7 [PMID:14512273]

43. Le TN, Elsea SH, Romero R, Chaiworapongsa T and Francis GL. (2013) Prolactin receptor gene polymorphisms are associated with gestational diabetes. Genet Test Mol Biomarkers 17: 567-71 [PMID:23651351]

44. Leaños-Miranda A, Campos-Galicia I, Ramírez-Valenzuela KL, Chinolla-Arellano ZL and IsordiaSalas I. (2013) Circulating angiogenic factors and urinary prolactin as predictors of adverse outcomes in women with preeclampsia. Hypertension 61: 1118-25 [PMID:23460287]

45. Lee SA, Haiman CA, Burtt NP, Pooler LC, Cheng I, Kolonel LN, Pike MC, Altshuler D, Hirschhorn JN and Henderson BE et al.. (2007) A comprehensive analysis of common genetic variation in prolactin (PRL) and PRL receptor (PRLR) genes in relation to plasma prolactin levels and breast cancer risk: the multiethnic cohort. BMC Med Genet 8: 72 [PMID:18053149] 
46. Lin SH, Arai AC, España RA, Berridge CW, Leslie FM, Huguenard JR, Vergnes M and Civelli O. (2002) Prolactin-releasing peptide (PrRP) promotes awakening and suppresses absence seizures. Neuroscience 114: 229-38 [PMID:12207968]

47. Lin SH, Leslie FM and Civelli O. (2002) Neurochemical properties of the prolactin releasing peptide (PrRP) receptor expressing neurons: evidence for a role of PrRP as a regulator of stress and nociception. Brain Res 952: 15-30 [PMID:12363400]

48. Marchese A, Heiber M, Nguyen T, Heng HH, Saldivia VR, Cheng R, Murphy PM, Tsui LC, Shi X and Gregor P et al.. (1995) Cloning and chromosomal mapping of three novel genes, GPR9, GPR10, and GPR14, encoding receptors related to interleukin 8, neuropeptide Y, and somatostatin receptors. Genomics 29: 335-44 [PMID:8666380]

49. Maruyama M, Matsumoto H, Fujiwara K, Kitada C, Hinuma S, Onda H, Fujino M and Inoue K. (1999) Immunocytochemical localization of prolactin-releasing peptide in the rat brain. Endocrinology 140: 2326-33 [PMID:10218986]

50. Maruyama M, Matsumoto H, Fujiwara K, Noguchi J, Kitada C, Fujino M and Inoue K. (2001) Prolactin-releasing peptide as a novel stress mediator in the central nervous system. Endocrinology 142: 2032-8 [PMID:11316770]

51. Maruyama M, Matsumoto H, Fujiwara K, Noguchi J, Kitada C, Hinuma S, Onda H, Nishimura O, Fujino $\mathrm{M}$ and Higuchi T et al.. (1999) Central administration of prolactin-releasing peptide stimulates oxytocin release in rats. Neurosci Lett 276: 193-6 [PMID:10612638]

52. Matsumoto H, Maruyama M, Noguchi J, Horikoshi Y, Fujiwara K, Kitada C, Hinuma S, Onda H, Nishimura O and Inoue K et al.. (2000) Stimulation of corticotropin-releasing hormone-mediated adrenocorticotropin secretion by central administration of prolactin-releasing peptide in rats. Neurosci Lett 285: 234-8 [PMID:10806329]

53. Matsumoto H, Noguchi J, Horikoshi Y, Kawamata Y, Kitada C, Hinuma S, Onda H, Nishimura O and Fujino M. (1999) Stimulation of prolactin release by prolactin-releasing peptide in rats. Biochem Biophys Res Commun 259: 321-4 [PMID:10362506]

54. Mong FY, Kuo YL, Liu CW, Liu WS and Chang LC. (2011) Association of gene polymorphisms in prolactin and its receptor with breast cancer risk in Taiwanese women. Mol Biol Rep 38: 462936 [PMID:21125332]

55. Morales T, Hinuma S and Sawchenko PE. (2000) Prolactin-releasing peptide is expressed in afferents to the endocrine hypothalamus, but not in neurosecretory neurones. J Neuroendocrinol 12: 131-40 [PMID:10718908]

56. Newey PJ, Gorvin CM, Cleland SJ, Willberg CB, Bridge M, Azharuddin M, Drummond RS, van der Merwe PA, Klenerman P and Bountra C et al.. (2013) Mutant prolactin receptor and familial hyperprolactinemia. N Engl J Med 369: 2012-20 [PMID:24195502]

57. Nieminen ML, Brandt A, Pietilä P and Panula P. (2000) Expression of mammalian RF-amide peptides neuropeptide FF (NPFF), prolactin-releasing peptide (PrRP) and the PrRP receptor in the peripheral tissues of the rat. Peptides 21: 1695-701 [PMID:11090924]

58. Nyante SJ, Faupel-Badger JM, Sherman ME, Pfeiffer RM, Gaudet MM, Falk RT, Andaya AA, Lissowska J, Brinton LA and Peplonska B et al.. (2011) Genetic variation in PRL and PRLR, and relationships with serum prolactin levels and breast cancer risk: results from a population-based case-control study in Poland. Breast Cancer Res 13: R42 [PMID:21470416]

59. O'Connor TM, O'Halloran DJ and Shanahan F. (2000) The stress response and the hypothalamicpituitary-adrenal axis: from molecule to melancholia. QJM 93: 323-33 [PMID:10873181]

60. Pereira Suarez AL, López-Rincón G, Martínez Neri PA and Estrada-Chávez C. (2015) Prolactin in inflammatory response. Adv Exp Med Biol 846: 243-64 [PMID:25472542]

61. Pflimlin E, Lear S, Lee C, Yu S, Zou H, To A, Joseph S, Nguyen-Tran V, Tremblay MS and Shen W. (2019) Design of a Long-Acting and Selective MEG-Fatty Acid Stapled Prolactin-Releasing Peptide Analog. ACS Med Chem Lett 10: 1166-1172 [PMID:31413801]

62. Pirník Z, Kolesárová M, Železná B and Maletínská L. (2018) Repeated peripheral administration of lipidized prolactin-releasing peptide analog induces c-fos and FosB expression in neurons of dorsomedial hypothalamic nucleus in male C57 mice. Neurochem Int 116: 77-84 [PMID:29601847]

63. Reis FM, Viganò P, Arnaboldi E, Spritzer PM, Petraglia F and Di Blasio AM. (2002) Expression of prolactin-releasing peptide and its receptor in the human decidua. Mol Hum Reprod 8: 356-62 [PMID:11912284]

64. Roland BL, Sutton SW, Wilson SJ, Luo L, Pyati J, Huvar R, Erlander MG and Lovenberg TW. (1999) Anatomical distribution of prolactin-releasing peptide and its receptor suggests additional functions in the central nervous system and periphery. Endocrinology 140: 5736-45 [PMID:10579339]

65. Sackmann-Sala L and Goffin V. (2015) Prolactin-induced prostate tumorigenesis. Adv Exp Med Biol 846: 221-42 [PMID:25472541]

66. Salazar-López-Ortiz CG, Hernández-Bueno JA, González-Bárcena D, López-Gamboa M, OrtizPlata A, Porias-Cuéllar HL, Rembao-Bojórquez JD, Sandoval-Huerta GA, Tapia-Serrano R and Vázquez-Castillo GG et al.. (2014) [Clinical practice guideline for the diagnosis and treatment of 
hyperprolactinemia]. Ginecol Obstet Mex 82: 123-42 [PMID:24779268]

67. Samson WK, Keown C, Samson CK, Samson HW, Lane B, Baker JR and Taylor MM. (2003) Prolactin-releasing peptide and its homolog RFRP-1 act in hypothalamus but not in anterior pituitary gland to stimulate stress hormone secretion. Endocrine 20: 59-66 [PMID:12668869]

68. Samson WK, Resch ZT and Murphy TC. (2000) A novel action of the newly described prolactinreleasing peptides: cardiovascular regulation. Brain Res 858: 19-25 [PMID:10700591]

69. Samson WK, Resch ZT, Murphy TC and Chang JK. (1998) Gender-biased activity of the novel prolactin releasing peptides: comparison with thyrotropin releasing hormone reveals only pharmacologic effects. Endocrine 9: 289-91 [PMID:10221595]

70. Satoh F, Smith DM, Gardiner JV, Mahmoodi M, Murphy KG, Ghatei MA and Bloom SR. (2000) Characterization and distribution of prolactin releasing peptide (PrRP) binding sites in the rat-evidence for a novel binding site subtype in cardiac and skeletal muscle. BrJ Pharmacol 129: 1787-93 [PMID:10780987]

71. Seal LJ, Small CJ, Dhillo WS, Kennedy AR, Ghatei MA and Bloom SR. (2002) Prolactin-releasing peptide releases corticotropin-releasing hormone and increases plasma adrenocorticotropin via the paraventricular nucleus of the hypothalamus. Neuroendocrinology 76: 70-8 [PMID:12169768]

72. Seal LJ, Small CJ, Kim MS, Stanley SA, Taheri S, Ghatei MA and Bloom SR. (2000) Prolactin releasing peptide (PrRP) stimulates luteinizing hormone (LH) and follicle stimulating hormone (FSH) via a hypothalamic mechanism in male rats. Endocrinology 141: 1909-12 [PMID:10803604]

73. Tachibana T and Sakamoto T. (2014) Functions of two distinct "prolactin-releasing peptides" evolved from a common ancestral gene. Front Endocrinol (Lausanne) 5: 170 [PMID:25426099]

74. Takahashi K, Totsune K, Murakami O, Sone M, Noshiro T, Hayashi Y, Sasano H and Shibahara S. (2002) Expression of prolactin-releasing peptide and its receptor in the human adrenal glands and tumor tissues of adrenocortical tumors, pheochromocytomas and neuroblastomas. Peptides 23: 1135-40 [PMID:12126742]

75. Tworoger SS, Eliassen AH, Zhang X, Qian J, Sluss PM, Rosner BA and Hankinson SE. (2013) A 20-year prospective study of plasma prolactin as a risk marker of breast cancer development. Cancer Res 73: 4810-9 [PMID:23783576]

76. Vaclavicek A, Hemminki K, Bartram CR, Wagner K, Wappenschmidt B, Meindl A, Schmutzler RK, Klaes R, Untch M and Burwinkel B et al.. (2006) Association of prolactin and its receptor gene regions with familial breast cancer. J Clin Endocrinol Metab 91: 1513-9 [PMID:16434456]

77. Vergoni AV, Watanobe H, Guidetti G, Savino G, Bertolini A and Schiöth HB. (2002) Effect of repeated administration of prolactin releasing peptide on feeding behavior in rats. Brain Res 955: 207-13 [PMID:12419538]

78. Watanabe TK, Suzuki M, Yamasaki Y, Okuno S, Hishigaki H, Ono T, Oga K, Mizoguchi-Miyakita A, Tsuji A and Kanemoto N et al.. (2005) Mutated G-protein-coupled receptor GPR10 is responsible for the hyperphagia/dyslipidaemia/obesity locus of Dmo1 in the OLETF rat. Clin Exp Pharmacol Physiol 32: 355-66 [PMID:15854142]

79. Welch SK, O'Hara BF, Kilduff TS and Heller HC. (1995) Sequence and tissue distribution of a candidate G-coupled receptor cloned from rat hypothalamus. Biochem Biophys Res Commun 209: 606-13 [PMID:7733930]

80. Yonezawa T, Chen KH, Ghosh MK, Rivera L, Dill R, Ma L, Villa PA, Kawaminami M and Walker AM. (2015) Anti-metastatic outcome of isoform-specific prolactin receptor targeting in breast cancer. Cancer Lett 366: 84-92 [PMID:26095602]

81. Zhang SQ, Kimura M and Inoué S. (2000) Effects of prolactin-releasing peptide (PrRP) on sleep regulation in rats. Psychiatry Clin Neurosci 54: 262-4 [PMID:11186069]

82. Zhang X, Danila DC, Katai M, Swearingen B and Klibanski A. (1999) Expression of prolactinreleasing peptide and its receptor messenger ribonucleic acid in normal human pituitary and pituitary adenomas. J Clin Endocrinol Metab 84: 4652-5 [PMID:10599733] 